\title{
PENGARUH PENGEMBANGAN SUMBER DAYA MANUSIA TERHADAP KINERJA PEJABAT STRUKTURAL DI LINGKUNGAN UNIVERSITAS MULAWARMAN
}

\author{
Oleh : \\ Syaharuddin $Y^{*}$ \\ ( ${ }^{\star}$ Dosen Fakultas Ekonomi Univeristas Mulawarman Samarinda)
}

\begin{abstract}
The purpose of this study was to Know and analyze any significant relationship between the ability of employees, education and training as well as experience working together on structural officials in environment the university Mulawarman and also to analyze the influence of dominant among employability, education and training, and experience work on structural officials in environment the university Mulawarman.

In this study used three variables studied, among others, the ability of employees (X1), education and latiha (X2) and work experience (X3). From the results of the regression analysis above, it can be arranged the following equation: $Y=0.521+0.252+0.577 \times 1 \times 2 X 3+0.219+e$

Variable capability of employee, Education and Training, Work Experience, simultaneously affect the performance of structural officials Mulawarman employees. Simultaneous influence on employee performance structural officials Mulawarman by $68.00 \%$, while the remaining $32.00 \%$, influenced the other, is evident from the results of the test $F$ by $F$ counts $F$ table value and significance value of $0.000<\alpha=0,05$, then the ability of work, education and training, work experience, affect the performance of structural officials attested employees university Mulawarman.
\end{abstract}

Keywords, ability of employees, education and training, and work experience

\section{PENDAHULUAN}

Dalam usaha untuk mencapai kinerja yang baik sangatlah ditentukan oleh beberapa faktor yang secara teoritis mempunyai keterkaitan yaitu antara lain : sistem kompensasi, lingkungan kerja, kualitas sumber daya manusia, factormotivasi, penguasaan teknologi budaya kerja dan lain - lain yang saling terkait antar satu dengan yang lainnya. Untuk mengetahui bagaimana peran aktif anggota organisasi, maka diperlukan penilaian kinerja yang kemudian dapat di tidak lanjuti dengan follow up pada kelemahan-kelemahan yang ada disesuaikan dengan standarisasi yang berlaku umum.

Kinerja setiap organisasi termasuk pejabat struktural di lingkungan Universitas Mulawarman sangat dipengaruhi berbagai faktor baik itu faktor internal seperti : Kemampuan Kerja, pendidikan dan latihan, pangalaman kerja, Deskripsi jabatan, spesifikasi jabatan, Disiplin kerja, motivasi kerja, 
kepemimpinan, budaya kerja dan lain-lain maupun faktor eksternal berupa lingkungan kerja dan lain-lain.

Selain faktor tersebut, sebagai manager atau pejabat skrutural tindakan antisipatif dan proaktif perlu dilakukan usaha-usaha yang mengarah pada peningkatan kemampuan dan keterampilan sumber daya manusia, misalnya dengan cara melakukan pendidikan dan latihan, on job training dan sebagainya. Sebagaimana halnya yang terjadi di lingkugan Universitas Mulawarma, peningkatan terhadap Sumber Daya Manusia dapat diawali dengan peningkatan kemampuan para pejabat skruturalnya lebih dulu dan selanjutnya dilakukan oleh pegawai lainnya. Dengan demikian kinerja karyawan dapat ditingkatkan sebagaimana yang diharapkan.

\section{Tujuan Penelitian}

1. Untuk mengetahui/menelaah secara empiris faktor - faktor : Kemampuan, Pendidikan dan latihan, serta Pengalaman kerja, apakah secara bersama sama mempunyai pengaruh yang bermakna terhadap kinerja pejabat struktural lingkungan Universitas Mulawarman.

2. Untuk membuktikan bahwa faktor tersebut diatas, secara persial mempunyai pengaruh yang bermakna terhadap kinerja pejabat struktural di lingkungan Universitas Mulawarman.

\section{TINJAUAN PUSTAKA}

\section{Pengembangan Sumber Daya Manusia}

Pada dasarnya apabila kita berbicara mengenai pengembangan sumber daya manusia secara menyeluruh, maka kita tidak akan terlepas dari keterkaitansemua aktivitas sumberdaya manusia pada suatu organisasi, yaitu di awali pada recruitmen and selection, placement, human resources development, research and development dan sebagainya. Karena tahap-tahap tersebut biasanya akan dilalui pada setiap anggota organisasi.

Hubungan antar karyawan yang kurang baik serta kondisi kerja yang kurang memungkinkan akan sangat menentukan kurangnya pengembangan sumberdaya manusia, dalam bentuk formal, pengembangan sumber daya manusia dilakukan melalui pendidikan dan pelatihan sedangkan dalam bentuk informal terlihat dari pengalaman kerja seorang karyawan.

Menurut Wilson Bangun (2012) menyatakan bahwa pengembangan Sumber Daya manusia adalah proses untuk meningkatkan pengetahuan dan keterampilan karyawan untuk mencapai tujuan yang efektif dan efisien.

Armstrong (1997) mengatakan bahwa Pengembangan sumber daya manusia sebagai pembentuk tingkah laku melalui pengalaman. Hal ini berkaitan dengan mangadakan persiapan untuk pegawai supaya bekerja lebih baik dalam pekerjaan sekarang dan mempersiapkan mereka untuk menerima tanggung jawab yang lebih besar dimasa yang akan datang.

Menurut Siagian (2007), bahwa bagi organisasi terdapat 7 (tujuh) manfaat yang dapat dipetik melalui penyelenggaraan Pengembangan Sumber Daya Manusia (PSDM), yaitu :

1. Peningkatan produktivitas kerja organisasi sebagai keseluruhan antara lain karena tidak terjadinya pemborosan, karena kecermatan melaksanakan tugas, tumbuh suburnya kerja sama antara berbagai satuan kerja yang melaksanakan kegiatan yang berbeda dan bahkan spesialistik, 
meningkatnya tekad mencapai sasaran yang telah ditetapkan serta lancarannya koordinasi sehingga organisasi bergerak sebagai suatu kesatuan yang bulat dan utuh.

2. Terwujudnya hubungan yang serasi antara atasan dan bawahan antara lain karena adanya pendelgasian wewenang, interaksi yang didasarkan pada sikap dewasa baik secara teknikal maupun intelektual, saling menghargai dan adanya kesempatan bagi bawahan untuk berpikir dan bertindak secara inovatif

3. Terjadinya proses pengembilan keputusan yang lebih cepat dan tepat karena melibatkan para pegawai yang bertanggung jawab menyelenggarakan kegiatan-kegiatan operasional dan tidak sekedar diperintahkan oleh para manajer

4. Meningkatkan semangat kerja seluruh tenaga kerja dalam organisasi dengan komitmen organisasional yang lebih tinggi

5. Mendorong sikap keterbukaan manajemen melalui penerapan gaya manajerial yang partisipatif

6. Memeperlancara jalannya komunikasi yang efektif yang pada gilirannya memperlancar proses perumusan kebijaksanaan organisasi dan operasionalisasinya

7. Penyelesaian konflik secara fungsional yang dampaknya adalah tumbuh suburnya rasa persatuan dan suasana kekeluargaan di kalangan para anggota organisasi.

\section{Kemampuan Pegawai}

Menurut Armstrong(2000) mengatakan bahwa : Tingkat kemampuan akan mempengaruhi bukan saja prestasi kerja, tetapi juga kepuasan kerja dan keinginan untuk tetap mempertahankan pekerjaannya.

Sedangkan Gibson(2003) mengatakan bahwa : Kemampuan menunjukkan potensi orang untuk melaksanakan tugas atau pekerjaan. Oleh sebab itu. Oleh sebab itu swasto (2005) mengatakan bahwa : setiap jenis pekerjaan menuntut pengetahuan, keterampilan dan sikap tertentu agar dapat melaksanakan pekerjaan tersebut dengan baik. Pengetahuan, keterampilan dan sikap yang dimiliki oleh seseorang karyawan akan menentukan kesepiannya untuk suatu pekerjaan .

Kemampuan keterampilan adalah : Kemampuan psiomotorik dan teknik pelaksanaan kerja tertentu. Sedangkan kemampuan sikap yakni kesiapsiagaan mental yang diorganisasi lewat pengalaman, yang mempunyai pengaruh tertentu kepada tanggapan seseorang terhadap orang-orang, obyek dan situasi yang berhubungan dengannya. Oleh sebab itu pula dapat dikatakan bahwa kombinasi atau perpaduan antara motivasi dan kemampuan karyawan sangat besar pengaruhnya terhadap optimasi prestasi kerja mereka, sehingga perlu mendapatkan perhatian yang serius.

\section{Pendidikan dan Latihan}

Menurut Wilson Bangun (2012) Pelatihan adalah untuk mempertahankan atau memperbaiki keterampilan karyawan untuk menghasilkan pekerjaan yang efektif.

Sedangkan Menurut Dessler (2005) Pelatihan adalah proses mengajar keterampilan yang dibutuhkan karyawan baru untuk melakukan pekerjaannya. 
Sedangkan menurut Moenir (2001) mengatakan bahwa : Pendidikan yakni : berkaitan dengan peningkatan pengetahuan umum dan pengertian atas seluruh lingkungan kerja.

Pelatihan yakni : berkaitan dengan peningkatan pengetahuan dan kemampuan dalam menjalankan pekerjaan tertentu dan merupakan beban penting bagi organisasi dimana pekerjaan itu berada.

Tujuan pendidikan dan latihan yakni :

a. Memelihara dan meningkatkan kecakapan dan kemam puan dalam menjalankan tugas/pekerjaan, baik pekerjaan lama maupun baru, baik dari segi peralatan maupun metode.

b. Menyalurkan keinginan pegawai untuk maju dari segi kemampuan dan memberikan rasa kebanggaan kepada mereka.

\section{Pengalaman Kerja}

Foster, (2001) Pengalaman kerja adalah sebagai suatu ukuran tentang lama waktu atau masa kerjanya yang telah ditempuh seseorang dalam memahami tugas-tugas suatu pekerjaan dan telah melaksanakannya dengan baik

Sedangkan menurut Kamisa (2000) mengatakan bahwa : Pengalaman kerja yakni yang pernah dialami (dijalani, dirasai, ditanggung dan sebagainya) semakin lama ia bekerja tentunya banyak keahlian dan keterampilan kerja yang ia dapatkan, selain itu dengan pengalaman didapat ide baru yang akan muncul sehingga setiap hasil akhir pekerjaan yang dijalankan akan bisa mendapat hasil yang baik.

Pengalaman kerja adalah kekuatan sosialisasi yang besar, diantaranya besarnya sikaf positif kelompok terhadap perusahaan, besarnya rasa percaya bahwa perusahaan akan memperhatikan keinginan dan minat karyawan, perasaan dibutuhkan oleh perusahaan dan besarnya harapan karyawan yang telah ditemukan dalam pekerjaan.

\section{Kinerja Penjabat}

Menurut David (2009) menyatakan bahwa, kinerja merupakan tahap dalam melaksanakan strategi bekerja dan perlu adanya disiplin, komitmen, pengorbanan personal dan penerapan strategi yang tergantung pada kemampuan dan pengetahuan. Dengan demikian maka kinerja mengacu pada prestasi karyawan yang diukur berdasarkan standar atau kriteria yang ditetapkan oleh perusahan atau instansi terkait. Tolak ukur dari kinerja adalah tuntunan yang menggambarkan hasil yang ingin dicapai.

Kinerja menurut Sulistiyani (2003), kinerja seseorang merupakan kombinasi dari kemampuan, usaha, dan kesempatan yang dapat dinilai dari hasil kerjanya. Sedangkan menurut Bernardin dan Russel dalam Sulistiyani (2003) menyatakan bahwa kinerja merupakan catatan outcome yang dihasilkan dari fungsi pegawai tertentu atau kegiatan yang dilakukan selama periode waktu tertentu.

Menurut As'ad (2005) kinerja diartikan sebagai prestasi yang diperlihatkan, kemampuan kerja yaitu seberapa jauh seseorang mampu melaksanakan pekerjaan dan dibandingkan dengan hasil yang ingin dicapai dinamakan kinerja seseorang tersebut pada pekerjaan tersebut.

Dengan demikian kinerja merupakan hasil yang dicapai seseorang menurut ukuran yang berlaku untuk pekerjaan yang bersangkutan. Jadi disini 
nampak bahwa pengertian kinerja dalam arti sempit hanya berkenaan dengan apa yang dihasilkan seseorang dalam pekerjaan.

Kinerja identik dengan performance, yaitu hasil kerja yang dicapai oleh seseorang atau sekelompok orang dalam suatu organisasi, sesuai dengan wewenang dan tanggung jawab masing-masing dalam rangka upaya mencapai tujuan organisasi bersangkutan secara legal, tidak melanggar hukum dan sesuai dengan moral dan etika (Suyadi, 2004)

Kinerja selalu berhubungan dengan prestasi yang dimiliki seseorang dalam menyelesaikan tugas-tugas individunya, dan kinerja juga merupakan persyaratan yang harus dimiliki setiap individu dalam menyelesaikan tugas. Kinerja karyawan dapat direfleksikan dalam tugasnya sebagai tenaga dalam bidang transportsi dan sebagai pelaksana administrasi kegiatan yang dilakukan dikantor. Dengan kata lain kinerja karyawan terlihat pada kegitan merencanakan, melaksanakan, dan mengevaluasikan proses kegiatan tranasportasi dengan kemampuan administrasi yang intensitasnya dilandasi etos kerja dan disiplin professional sebagai karyawan.

Lebih lanjut Suyadi (2004) menyatakan, kinerja merupakan suatu proses yang dilakukan untuk menggerakkan karyawan agar dapat diarahkan pada upaya-upaya yang nyata untuk mencapai tujuan yang telah ditetapkan. Besar kecilnya seseorang biasanya memiliki kemampuan dan motivasi tinggi akan menghasilkan kinerja yang optimal, begitu juga sebaliknya. Berdasarkan uraian diatas dapat disimpulkan bahwa kinerja karyawan adalah performance yaitu gambaran hasil kerja karyawan atau unjuk kerja karyawan yang berkaitan dengan tugas yang diembannya dan didasarkan atas tanggung jawab profesional yang dimiliki karyawan tersebut. Hal ini di tunjukkan pada kualitas kerjanya, kecepatan dan ketepatan kerja, inisiatif dalam kerja, kemampuan dalam kerja, dan kemampuan mengkomunikasikan hasil kerja.

Sehubungan dengan penjelasan dan paparan di atas, maka dalam penelitian ini Pengaruh Pengembangan Sumber Daya Manusia Terhadap Kinerja Pejabat Struktural di Lingkungan Universitas Mulawarman di tunjukkan dalam gambar di bawah ini :

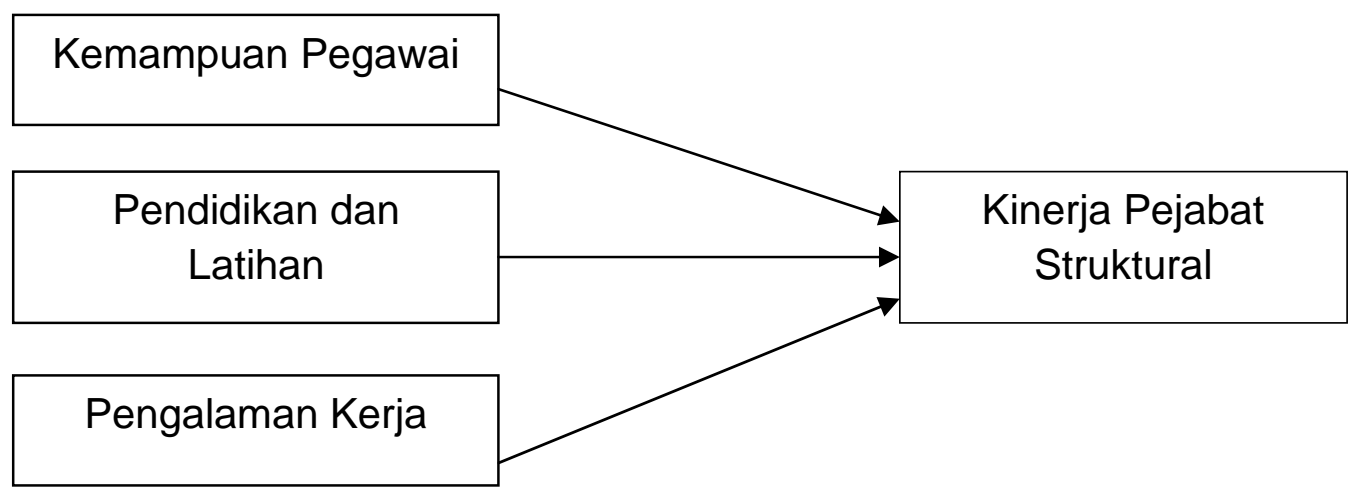

\section{Hipotesis}

Sehubungan dengan hal tersebut, maka penulis kemukakan rumusan hipotesis dalam penelitian sebagai berikut:

1. Kemampuan kerja, berpengaruh terhadap kinerja pejabat struktural di lingkungan Universitas Mulawarman. 
2. Pendidikan dan Latihan berpengaruh terhadap kinerja pejabat struktural di lingkungan Universitas Mulawarman.

3. Pengalaman Kerja, berpengaruh terhadap kinerja pejabat struktural di lingkungan Universitas Mulawarman.

\section{METODE PENELITIAN}

\section{Populasi dan Sampel}

Dalam penelitian ini yang menjadi populasi adalah pegawai pejabat Struktural Universitas Mulawarman. Jumlah sampel yang diambil dalam penelitian ini dengan menggunakan dasar teori milik Gay dan Diehl, yang berpendapat bahwa semakin besar sampelnya maka kecenderungan lebih representative, hasilnya dapat digeneralisasi. Sehingga dalam penelitian ini menggunakan sampel 70 pegawai pejabat struktural Universitas Mulawarman

\section{Analisis Data}

Analisis regresi

Untuk menentukan persamaan garis regresi menggunakan bantuan program SPSS versi 19.0 maka akan diperoleh hasil persamaan analisis regresi, yang digunakan untuk mengetahui pengaruh suatu variabel terikat dengan satu atau lebih variabel bebas.

Menurut Sunyoto (2010:29) memberikan bentuk umum dari regresi dapat dirumuskan seperti persamaan berikut :

Keterangan :

$$
Y=a+b_{1} X_{1}+b_{2} X_{2}+b_{3} X_{3}+e
$$

$\begin{array}{lll}\mathrm{a} & = & \text { konstanta } \\ \mathrm{b}_{1} \mathrm{~b}_{2} \mathrm{~b}_{3} & = & \text { koefisien regresi } \mathrm{X}_{1} \text { sampai } \mathrm{X}_{3} \text { terhadap } \mathrm{Y} \\ \mathrm{X}_{1} & = & \text { Kemampuan pegawai } \\ \mathrm{X}_{2} & = & \text { Pendidikan dan latihan } \\ \mathrm{X}_{3} & = & \text { Pengalaman kerja } \\ \mathrm{Y} & = & \text { Kinerja }\end{array}$

\section{HASIL PEELITIAN}

\section{Pengaruh Kemampuan Pegawai}

Dari hasil perhitungan statistik dengan bantuan SPSS 19.0 for window diperoleh hasil bahwa $\mathrm{t}_{\text {hitung }}=3,341>\mathrm{t}$ tabel $=1,669$ dengan nilai signifikan sebesar $0,001<0,05$ hal ini mengandung arti bahwa apabila Kemampuan yang terdiri dari kemampuan dan ketrampilan mengoperasionalkan komputer, kemampuan bekerjasama, kemampuan di bidang kerja yang di miliki pejabat struktural sudah optimal untuk mendukung kinerja pejabat struktural dilingkungan Universitas mulawarman. Hal ini sejalan dengan teori Gibson bahwa kemampuan menunjukkan potensi orang untuk melaksanakan tugas atau pekerjaan yang akan berpengaruh terhadap kinerja pegawai tersebut.

\section{Pengaruh Pendidikan dan Latihan}

Dari hasil perhitungan statistik dengan bantuan SPSS 19.0 for window diperoleh hasil bahwa $\mathrm{t}_{\text {hitung }}=7,175>\mathrm{t}$ tabel $=1,669$ dengan nilai signifikan sebesar $0,000<0,05$ hal ini mengandung arti bahwa apabila pendidikan formal dan pelatihan serta kursus yang ditempuh oleh pejabat 
mempunyai kontribusi yang bermakna dalam meningkatkan kinerja pejabat tersebut. Hasil penelitian ini sejalan dengan teori Nitisemito bahwa : Latihan merupakan suatu kegiatan dari instansi/perusahaan yang bermaksud untuk dapat memperbaiki dan memperkembangkan sikap, tingkah laku, keterampilan dan pengetahuan para pegawai/karyawan sesuai dengan keinginan dari instansi/perusahaan yang bersangkutan.

\section{Pengaruh Pengalaman Kerja}

Dari hasil perhitungan statistik dengan bantuan SPSS 19.0 for window diperoleh hasil bahwa $\mathrm{t}$ hitung $=2,874>\mathrm{t}$ tabel $=1,669$ dengan nilai signifikan sebesar $0,005<0,05$ hal ini mengandung arti bahwa apabila pengalaman yang dialami pejabat yang terdiri dari masa kerja, golongan dan jabatan yang dipegang selama ini mampu memberikan kontribusi yang optimal terhadap kinerja pejabat struktural.

\section{KESIMPULAN}

Berdasarkan hasil analisis dan pembahasan hasil penelitian maka disajikan beberapa kesimpulan sebagai berikut :

1. Variabel Kemampuan kerja, Pendidikan dan Latihan, serta Pengalaman Kerja, secara simultan berpengaruh terhadap Kinerja pejabat struktural pegawai Universitas Mulawarman. Pengaruh yang dijelaskan variabel Kemampuan kerja, Pendidikan dan Latihan, serta Pengalaman Kerja, secara simultan terhadap Kinerja pejabat struktural pegawai Universitas Mulawarman sebesar $68,00 \%$, sisanya sebesar $32,00 \%$, di pengaruhi yang lain, terbukti dari hasil uji $\mathrm{F}$ dengan nilai $\mathrm{F}$ hitung >nilai $\mathrm{F}$ tabel dan nilai signifikasinya sebesar $0,000<\alpha=0,05$, maka hipotesis yang menyatakan bahwa Kemampuan kerja, Pendidikan dan Latihan, serta Pengalaman Kerja, berpengaruh terhadap Kinerja pejabat struktural pegawai universitas Mulawarman terbukti kebenarannya atau hipotesis diterima.

2. Secara partial hubungan antara variabel independent yang terdiri dari Kemampuan kerja, Pendidikan dan Latihan, serta Pengalaman Kerja, terhadap variabel dependent Kinerja berdampak positif. Tetapi nilai koefisien beta dari tiga variabel independent tersebut, variabel Pendidikan dan Latihan berpengaruh dominan terhadap kinerja pejabat struktural pegawai Universitas Mulawarman.

\section{DAFTAR PUSTAKA}

As'ad, M. 2004. Psikologi Industri, Seri Umum. Sumber Daya Manusia. Edisi 4. Liberty, Yogyakarta.

Bangun Wilson, 2012. Manajemen Sumber Daya Manusia, Erlangga, Jakarta

Dessler Gary, 2009, Manajemen Sumber Daya Manusia, Edisi 10, Alih Bahasa Paramita Rahayu, , Indeks, Jakarta

Foster, Bil. 2001. Pembinaan untuk Peningkatan Kinerja Karyawan. PM. Jakarta. 
Fred R. David, 2009, Manajemen Strategis. Salemba Empat Jakarta .

Hasibuan, Melayu. 2004. Organisasi dan Motivasi Dasar Peningkatan Produktivitas. Bumi Aksara, Jakarta

Kamisa, 2007, Kamus Lengkap Bahasa Indonesia, Kartika, Surabaya

Kepner H. Charles. 2003. Manajer Yang Rasional Cetakan Ke Tiga. Alih Bahasa Anton Susanto. Erlangga, Jakarta

Kuncoro, Mudrajat. 2004, Metode Kuantitatif : Teori dan Aplikasi untuk Bisnis dan Ekonomi, Edisi kesatu, UPP AMP YKPN, Yogyakarta

Mangkunegara, Anwar Prabu, A.A. 2005. Perilaku dan Budaya Organisasi. Refika Aditama. Bandung.

Siagian, Sondang P. 2004. Manajemen Sumber Daya Manusia. Remaja Rosdakarya, Jakarta

Simamora, Henri. 2004. Manajemen Sumber Daya Manusia edisi III. Yogyakarta. STIE YKPN Yogyakarta

Sugiyono, (2010), Metode Penelitian Kuantitatif Kualitatif \& RND, Alfabeta, Bandung

Thoha Miftah, M. 2010. Kepemimpinan dalam Manajemen. Raja Grafindo Persada, Jakarta.

Tika, P. 2006. Budaya Organisasi Dan Peningkatan Kinerja Perusahaan. PT Bumi Aksara, Jakarta.

Tjiptono, Fendi dan Anastasia, Diana. 2007. Total Quality Management. Andi, Yogyakarta. 